\title{
CUSTOMER LOYALTY MEASUREMENT AT CZECH ORGANIZATIONS
}

\author{
DOI: 10.12776/QIP.V17I1.66
}

\author{
DAVID VYKYDAL, PETRA HALFAROVÁ, JAROSLAV NENADÁL
}

\section{INTRODUCTION}

Some organisations can consider their customers in two ways: either they exist or they do not. But organisations without their customers cannot survive from the long term perspective. Therefore, questions related to customer retention or customer loyalty seem to be crucial today. Unfortunately, there are no requirements for customer loyalty monitoring or measurement in the latest version of the ISO 9001 standard - the ISO is only able to require customer satisfaction measurement - see (ISO/TS 10004, 2011), for example. And more: the ISO 9004:2009 standard, which is focused on managing for sustained success of the organizations (ISO 9004, 2009), does not mention this field either! On the other hand: every other description of business excellence models contains some guidance points towards customer loyalty measurement or management. The EFQM Excellence Model can serve as a positive example (EFQM, 2013).

\section{THE LOYALTY CONCEPT}

But what is customer loyalty? Recognized definition of this term came from F. Reichheld, who wrote that it was "willingness to make an investment or personal sacrifice to strengthen a relationship" (Reichheld, 1996). From the psychological point of view, customer loyalty has been defined as a behavioral measure (Oliver, 1997) or as repeat purchase behavior led by favorable attitudes or as a consistent purchase behavior resulting from the psychological decisionmaking. (Jacoby \& Kyner, 1973). Some authors refer to a similar concept as behavioral intentions that include renewing the contract Smith \& Barclay (1999), Woo \& Ennew (2004), Berry \& Parasuraman (1991). The concept of customer loyalty is understood as a combination of customers' favourable attitude and the behaviour of repurchase.

Bowen and Shoemaker (2003) define customer loyalty as "a construct that measures the probability the customer will return and is ready to perform partnering activities such as referrals, in terms of repeated purchases". We can 
also see the customer loyalty as purchase frequency, (Brody \& Cunningham, 1968), (Kahn, et al., 1986), or multiple aspects of purchase behavior (Ehrenberg, 1988).

Other authors work with the definition of loyalty as a certain emotional or affective commitment (Cater \& Zabkar, 2009), (de Ruyter et al., 2001), (Rauyruen \& Miller, 2007), (Wetzels et al., 1998). These authors examine whether affective commitment affects loyalty and how. This emotional commitment may result in positive references about the brand or company (Harrison-Walker, 2001), or highly subjective loyalty to the brand (Evanschitzky, et al., 2006). This attachment and positive relationship with the brand can contribute to the "partnership" between the customer and the company. (Evanschitzky, et al., 2006).

Now - from the perspective of advanced quality management, we can declare that customer loyalty is the way of their future behaviour, showing his/her likelihood to purchase again as well as to recommend the product or brand to others. Such behaviour sticks with business over time. Substantial experience says that customer loyalty can be seen as the key determinant of each company's profitability or success. That is why the customer loyalty measurement should be an important part of the overall customer feedback, monitored usually through periodic surveys.

The most simple customer loyalty indicator is known as the Net Promoter Score (NPS). It is usually calculated from answers to the only question: "How likely are you to recommend us to your friends or colleagues?" On the basis of their response to this question, customers are segmented into three groups: detractors (low rating), passives and promoters (high rating). NPS is calculated as:

$$
\text { NPS = Number of promoters }- \text { Number of detractors. }
$$

Nokia has been using this indicator for some years, for example (EFQM, 2010). But we can discover some serious limitations of such approach - see (Hayes, 2009). NPS is mostly seen as an "old - fashioned" indicator at present.

Commonly, when measuring customer loyalty, we can now work with several objective measures which could be derived from such features as:

- Number of referrals;

- Purchase of the same products again;

- Purchase of another product from our offer;

- Increasing purchase size and:

- Customer retention or customer defection. 


\section{THE CURRENT STATE OF CUSTOMER LOYALTY MEASUREMENT AT CZECH ORGANIZATIONS}

In spite of the world-wide recognized significance of customer loyalty measurement, the most of Czech organizations have no systematic approach to this type of measurement. Czech organizations only conduct customer satisfaction monitoring or measurement, as it is the requirement of the ISO 9001:2008 standard. Therefore, we have tried to discover the reasons and shortcomings related to customer loyalty measurement in Czech companies.

First of all: we defined basic hypothesis: the most of Czech organizations have no systematic approach to customer loyalty measurement.

To confirm this hypothesis a relevant field research was performed. Such techniques as focus group, interview and questionnaire survey were used on this purpose. Here is a brief description of main steps as well as of some results of our activities.

1) We fully realized the poor state of local customer loyalty measurement when we tried to identify the main risks related to development and implementation of the quality management system in Czech organizations. A special set of activities were performed on this purpose during autumn 2010. We were inspired by the ISO Guide 73, which defines risk as "the effect of uncertainty on objectives" (ISO Guide 73, 2009). The effect is understood as a deviation from the expected or planned state. Such state is usually described through strategic quality objectives in a quality management system. This guide also notes that uncertainty could be the state of deficiency of information related to understanding or knowledge of a certain event. We can view the risk as the probability of occurrence of a particular situation or event over a period of time, a situation or event which will have an impact upon organizations' objectives. As we know, the quality management system must be based on certain principles. Let us remind the basic principles according to the ISO 9000 family of standards - see Annex B at (ISO 9004, 2009) for example:

- Customer focus

- Leadership

- Involvement of people

- Process approach

- Systems approach to management

- Factual approach to decision making

- Continual improvement

- Mutually beneficial supplier relationship. 
2) To identify the most serious risks related to each of the mentioned quality management principles, we organized special workshops with 36 very experienced quality managers from various Czech companies. A focus group technique was used to openly discuss individual opinions. Because of the relative subjectivity, we held six focus group sessions (each group was composed of six quality managers). A particular list of risks was the result of each focus group. Finally, all participants were required to reach a consensus about the most serious risks: only one of the identified risks could be assigned to each quality management principle. The results of such consensus are summed up in Table 1.

Table 1 - The most serious risks associated with quality management principles in Czech companies - (own research)

\begin{tabular}{|c|c|c|}
\hline $\begin{array}{l}\text { Quality } \\
\text { management } \\
\text { principle } \\
\end{array}$ & Definition of the principle (ISO, 9004) & The most serious risk \\
\hline $\begin{array}{l}\text { Customer } \\
\text { focus }\end{array}$ & $\begin{array}{l}\text { "Organizations depend on their customers } \\
\text { and therefore should understand the current } \\
\text { and future customer needs, should meet the } \\
\text { customer requirements and strive to exceed } \\
\text { customer expectations." }\end{array}$ & $\begin{array}{l}\text { Customer loyalty and } \\
\text { customer value are not } \\
\text { measured in a } \\
\text { systematic manner. }\end{array}$ \\
\hline Leadership & $\begin{array}{l}\text { "Leaders establish the unity of purpose and } \\
\text { direction of the organization. They should } \\
\text { create and maintain the internal environment } \\
\text { in which people can become fully involved in } \\
\text { achieving the organization's objectives." }\end{array}$ & $\begin{array}{l}\text { Quality policy and } \\
\text { quality objectives are } \\
\text { not derived from the } \\
\text { organizations' mission, } \\
\text { vision and values. }\end{array}$ \\
\hline $\begin{array}{l}\text { Involvement } \\
\text { of people }\end{array}$ & $\begin{array}{l}\text { "People at all levels are the essence of an } \\
\text { organization and their full involvement } \\
\text { enables their abilities to be used for the } \\
\text { organization's benefit." }\end{array}$ & $\begin{array}{l}\text { Knowledge sharing is } \\
\text { not a company value. }\end{array}$ \\
\hline $\begin{array}{l}\text { Process } \\
\text { approach }\end{array}$ & $\begin{array}{l}\text { "A desired result is achieved more efficiently } \\
\text { when activities and related resources are } \\
\text { managed as a process." }\end{array}$ & $\begin{array}{l}\text { An incorrect process } \\
\text { performance } \\
\text { measurement } \\
\text { methodology is used. }\end{array}$ \\
\hline $\begin{array}{l}\text { Systems } \\
\text { approach to } \\
\text { management }\end{array}$ & $\begin{array}{l}\text { "Identifying, understanding and managing } \\
\text { interrelated processes as a system } \\
\text { contributes to the organization's } \\
\text { effectiveness and efficiency in achieving its } \\
\text { objectives." }\end{array}$ & $\begin{array}{l}\text { Interrelations among } \\
\text { processes are not } \\
\text { described and } \\
\text { understood. }\end{array}$ \\
\hline $\begin{array}{l}\text { Factual } \\
\text { approach to } \\
\text { decision } \\
\text { making }\end{array}$ & $\begin{array}{l}\text { "Effective decisions are based on the } \\
\text { analysis of data and information." }\end{array}$ & $\begin{array}{l}\text { Reviews of the leading } \\
\text { organizations } \\
\text { performance are not } \\
\text { performed } \\
\text { systematically. }\end{array}$ \\
\hline
\end{tabular}




\begin{tabular}{|l|l|l|}
\hline $\begin{array}{l}\text { Continual } \\
\text { improvement }\end{array}$ & $\begin{array}{l}\text { "Continual improvement of the } \\
\text { organization's overall performance should } \\
\text { be a permanent objective of the } \\
\text { organization." }\end{array}$ & $\begin{array}{l}\text { Corrective actions have } \\
\text { a priority over product } \\
\text { or process innovations. }\end{array}$ \\
\hline $\begin{array}{l}\text { Mutually } \\
\text { beneficial } \\
\text { supplier } \\
\text { relationship }\end{array}$ & $\begin{array}{l}\text { "An organization and its suppliers are } \\
\text { interdependent and a mutually beneficial } \\
\text { relationship enhances the ability of both to } \\
\text { create value." }\end{array}$ & $\begin{array}{l}\text { In most cases, } \\
\text { partnership with } \\
\text { suppliers is } \\
\text { underestimated. }\end{array}$ \\
\hline
\end{tabular}

3) It stands to reason that these risks should be assessed. A simple 3 by 3 qualitative risk matrix was used, as it was easy to use and understandable for all participants. Three ranges of likelihood of certain risk occurrence as well as consequences (impact on quality management system performance) were identified. Then, each risk from table 1 was assessed and placed in the risk matrix. The result of the qualitative risk assessment is illustrated in Figure 1. It is evident that the risk defined as "Customer loyalty and customer value are not measured" was recognized as the most serious one. How can such finding be explained? The participants described the reality (customer loyalty is not measured) on the one hand, but they also admitted that such measurement is crucial from the viewpoint of the overall company success. The lack of systematic approach to customer loyalty monitoring and measurement is commonly recognized as the key weakness or area for improvement.

\begin{tabular}{|c|c|c|c|}
\hline $\begin{array}{l}\text { Very } \\
\text { likely }\end{array}$ & & $\begin{array}{l}\text { Reviewing the leading } \\
\text { organizations } \\
\text { performance is not made } \\
\text { systematically. } \\
\text { - Corrective actions have a } \\
\text { priority before product or } \\
\text { process innovations. }\end{array}$ & $\begin{array}{l}\text { - Customer loyalty and } \\
\text { customer value are not } \\
\text { measured by systematic } \\
\text { manner. } \\
\text { - Partnership with suppliers is } \\
\text { mostly underestimated. }\end{array}$ \\
\hline Likely & & $\begin{array}{l}\text { Quality policy and quality } \\
\text { objectives are not derived } \\
\text { from organizations' } \\
\text { mission, vision and } \\
\text { values. }\end{array}$ & $\begin{array}{l}\text { - An incorrect process } \\
\text { performance measurement } \\
\text { methodology is there used. } \\
\text { - Knowledge sharing is not a } \\
\text { company value. }\end{array}$ \\
\hline \multirow[t]{2}{*}{ Unlikely } & & $\begin{array}{l}\text { Interrelations among } \\
\text { processes are not } \\
\text { described and understood. }\end{array}$ & \\
\hline & Minor & Moderate & Major \\
\hline
\end{tabular}

Figure 1 - Qualitative risk matrix (L-likelihood of risk occurrence, I-overall impact on quality management system performance - own research) 
4) We had to verify these findings. Therefore, a special questionnaire survey was conducted during spring 2012. A total of 183 organizations operating in metallurgical industry were addressed in a survey. The purpose of the effort was to find whether they engage in customer loyalty measurement and what approach they rely on. The rate of return of questionnaires was just below 19\%: out of 183 questionnaires sent, 34 returned. The survey revealed that less than one third of the organizations conduct customer loyalty measurement (Figure 2). In addition, it transpires that customer loyalty measurement is practised primarily by those organizations whose quality management system had been implemented in accordance to some of the available standards (ISO 9001, ISO/TS 16 949, ...). But: there was just one respondent claiming to conduct customer loyalty measurement, while not having a quality management system certificate. In addition, it was found that the size of the organization is not a decisive factor: the customer loyalty measurement is performed equally by small, medium-sized and large organizations.

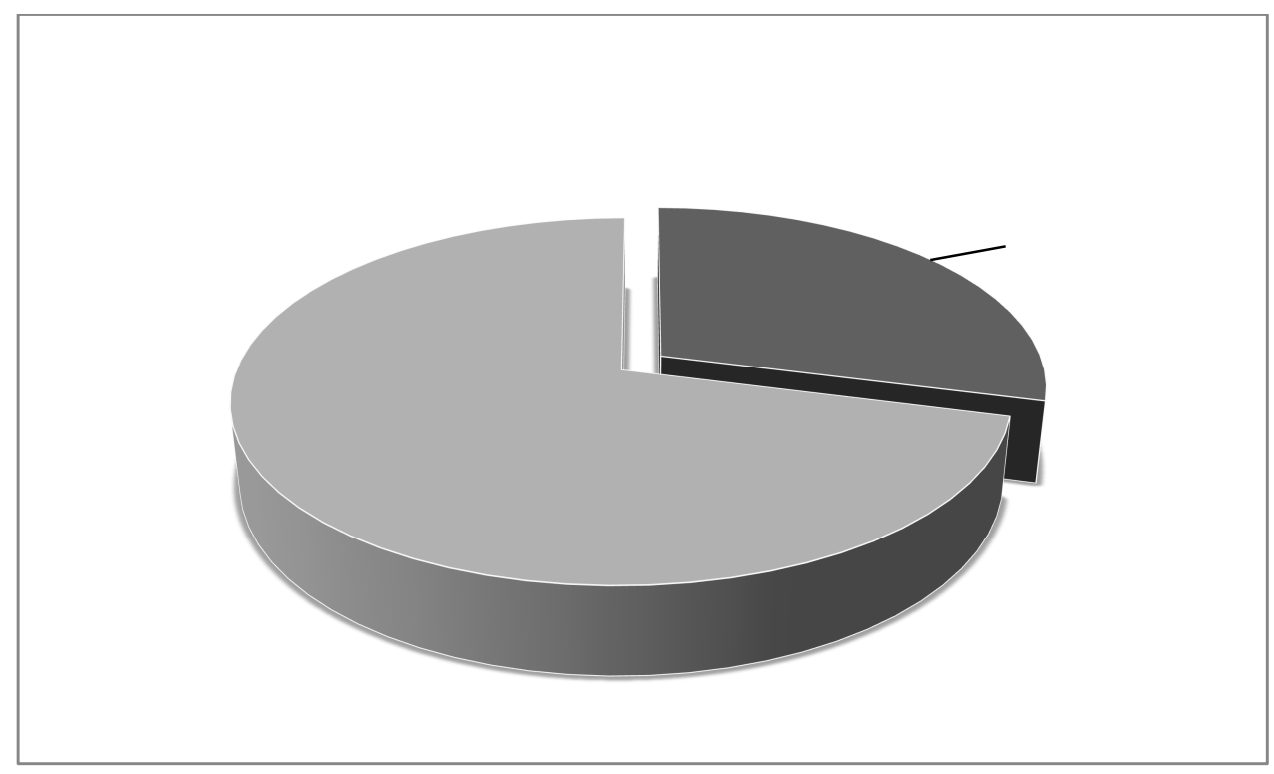

Figure 2 - Customer loyalty measurement in organizations in metallurgical industry (own research)

Every organization had its own reasons for engaging in customer loyalty measurement, such as: customer loyalty measurement being integrated in the customer care process, used as part of marketing analyses for strategic planning, initiated by a request of the parent company or a recommendation of the EFQM Excellence Model, conducted as part of customer satisfaction surveys or used as a tool for improving economic performance and company image. The most frequently mentioned reason was systematic customer care. At the same time, however, the organizations gave reasons why they did not measure customer loyalty. The general summary of these reasons can be rephrased as: "It is not necessary, as no one requires us to do this/We do not know how customer loyalty can be measured." 
Another part of the survey comprised questions aimed at the approaches and indicators used by those organizations which do measurement of customer loyalty. Those revealed that the most frequent approach is the measurement of future intentions. The most common indicators include the sales volume per customer, customer retention and long-term relationship (as shown in Table 2), as the last column in the table identifies ratio of respondents who have declared exploatation of such indicator to the total number of respondents.

Tabel 2 - Customer loyalty measurement approaches and indicators (own research).

\begin{tabular}{|l|l|c|}
\hline \multicolumn{1}{|c|}{ Approach } & \multicolumn{1}{|c|}{ Indicator } & \% \\
\hline \multirow{2}{*}{$\begin{array}{l}\text { Measurement of future } \\
\text { intentions }\end{array}$} & Sales volume per customer & 60 \\
\cline { 2 - 3 } & Customer retention & 50 \\
\hline \multirow{2}{*}{$\begin{array}{l}\text { Measurement of acquired } \\
\text { and lost customers }\end{array}$} & Long-term relationship & 40 \\
\cline { 2 - 3 } & $\begin{array}{l}\text { Product quality, technical design of products, } \\
\text { job realization, delivery times, price level }\end{array}$ & 10 \\
\hline \multirow{2}{*}{$\begin{array}{l}\text { Measurement of loyalty } \\
\text { effects }\end{array}$} & Potential competition & 10 \\
\cline { 2 - 3 } & $\begin{array}{l}\text { Ratio between the numbers of new customers } \\
\text { and all customers }\end{array}$ & 10 \\
\hline \multirow{2}{*}{$\begin{array}{l}\text { Measurement of } \\
\text { competitive environment }\end{array}$} & Number of lost and acquired customers & 10 \\
\cline { 2 - 3 } & Market share of our products \\
\hline
\end{tabular}

The survey confirmed the notions that the awareness of customer loyalty measurement is not embedded adequately in the organizations and most organizations will not engage in it, unless being forced. Our hypothesis was approved. This situation will not be close to changing, unless the organizations become familiar with procedures for customer loyalty measurement and begin to understand the benefits to be reaped.

\section{THE PROPOSAL OF CUSTOMER LOYALTY MEASUREMENT AT CZECH COMPANIES}

It is clear that such unfavourable findings call for a relevant response. That is why we have begun developing an advanced methodology for customer loyalty measurement with a special regard to industrial customers (consumers) of metallurgical producers. Such methodology ought to go far beyond the Net Promoter Score calculation. We accepted as the suitable base the B.E. Hayes' approach who distinguishes three fundamental types of customer loyalty: 
- Advocacy;

- Purchasing; and

- Retention.

Advocacy loyalty reflects the degree to which customers will play a role of advocates by way of recommendations, choose the same product again, etc. Purchasing loyalty reflects the degree to which customers will increase their purchasing behaviour, including purchasing different products. And finally: the retention loyalty reflects the degree to which customers will remain loyal to the same company (Hayes, 2009). Such types of customer loyalty had to be measured through relevant indicators. The fundamental list of these indicators is presented in Table 3.

Table 3 - Customer loyalty: behaviour proposed for measuring (own research).

\begin{tabular}{|l|l|}
\hline Type of customer loyalty & Loyalty index related to loyalty factor: \\
\hline Advocacy loyalty & $\begin{array}{l}\text { Overall satisfaction } \\
\text { Choose the product again } \\
\text { Recommendations }\end{array}$ \\
\hline Purchasing loyalty & $\begin{array}{l}\text { Purchase different products } \\
\text { Purchase more expensive } \\
\text { Purchase more often } \\
\text { Purchase larger }\end{array}$ \\
\hline Retention loyalty & $\begin{array}{l}\text { Purchase from competitors } \\
\text { Stop purchasing } \\
\text { Switch to another supplier }\end{array}$ \\
\hline
\end{tabular}

Within each type of customer loyalty, a loyalty level should be quantified. For example, the purchasing loyalty level - PLL is calculated using the following formula:

$$
P L L=0,25\left(P_{p d p}+P_{p e p}+P_{p i p}+P_{p l p}\right)
$$

Where:

$P_{p d p}$ - probability of purchasing different products,

$P_{p e p}$ - probability of purchasing more expensive products,

$P_{p i p}$ - probability of increasing of total number of purchasing,

$P_{p l p}$ - probability of larger purchasing. 
For all kinds of probabilities, the same formula can be used: number of customers who declared certain intention without any hesitation divided by the survey sample size. The final version of this methodology will be verified through a pilot project next year. The results or lessons learned will be presented as soon as possible.

\section{CONCLUSION}

The customer loyalty measurement represents very seldom used approach to quality management systems feedback at Czech companies till the time. Our proposal of customer loyalty measurement, based on B. E. Hayes' approach, is quite now and applicable at any Czech business area, not only at metallurgical organisations. It is our scientific conribution to the quality management systems development, as well as the findings from the field survey The practical impact can be found especially in fact that various organisations can use our methodology when they want to discover how the customer behaviour influence overall organisation performance.

\section{ACKNOWLEDGEMENT}

This paper was elaborated in the frame of the specific research project No. SP2012/37, which has been solved at the Faculty of Metallurgy and Materials Engineering, VŠB-TU Ostrava with the support of Ministry of Education, Youth and Sports, Czech Republic.

\section{REFERENCES}

Berry, L. L., Parasuraman, A., 1991. Marketing services: Competing through quality. New York: The Free Press.

Bowen, J. T., Shoemaker, S., 2003. Loyalty: A strategic commitment. Cornell Hotel and Restaurant Administration Quarterly, 44(5/6), p. 31-46.

Brody, Robert P., Cunningham, Scott M., 1968, Personality variables and the consumer decision process. Journal of Marketing Research.

Cater, B., Zabkar, V., 2009. Antecedents and consequences of commitment in marketing research services: The client's perspective. Industrial Marketing Management, 38(7), p. 785-797.

de Ruyter, K., Moorman, L., Lemmink, J. 2001. Antecedents of commitment and trust in customer-supplier relationships in high technology markets. Industrial Marketing Management, 30(3), p. 271-286.

EFQM, 2010. Improvement feedback in real time: the Net Promoter Score at Nokia. <http://www.efqm.org/en/newsletter/> [Accessed $2^{\text {nd }}$ of September 2010]. 
EFQM, 2013. EFQM Excellence Model. Brussels: EFQM. 2013, 29 p.

Ehrenberg, A. 1988. Repeat buying: Theory and applications (2nd edition). London: Charles Griffin \& Co.

Evanschitzky, H., Iyer, G. R., Plassmann, H., Niessing, J., \& Meffert, H., 2006. The relative strength of affective commitment in securing loyalty in service relationships. Journal of Business Research, 59(12), p. 1207-1213.

Harrison-Walker, J. L. 2001. The measurement of word-of-mouth communication and an investigation of service quality and customer commitment as potential antecedents. Journal of Service Research, 4(1), p. 60-75.

Hayes, B. E. 2009. Beyond Ultimate Question. A Systematic Approach to Improve Customer Loyalty. Milwaukee: ASQ Quality Press, 396 p.

ISO, 2009. ISO Guide 73, Risk Management - Vocabulary. Geneve: ISO, 2009

ISO, 2011. ISO/TS 10004. Quality management - Customer satisfaction guidelines for monitoring and measuring. Geneve: ISO. 2011

ISO, 9004. Managing for the sustained success of an organization - A quality management approach. Geneve: ISO. 2009

Jacoby, J., Kyner, D. B., 1973, Brand loyalty vs. repeat purchasing behavior. Journal of Marketing Research 10 (1), p. 1-9.

Kahn, B. E., Kalwani, M. U., Morrison, D. G. 1986. Measuring variety-seeking and reinforcement behaviors using panel data. Journal of Marketing Research, 23(2).

Oliver, R. L., 1997. Satisfaction: A behavioral perspective on the consumer. Boston: Irwin McGraw-Hill.

Rauyruen, P., Miller, K. E., 2007. Relationship quality as a predictor of B2B customer loyalty. Journal of Business Research, 60(1), p. 21-31.

Reichheld, F. 1996. The Loyalty Effect: The Hidden Force Behind Growth, Profit and Lasting Value. Harvard Business School Press, 352 p.

Smith, J. B., Barclay, D. W., 1999. Selling partner relationships: The role of interdependence and relative influence. Journal of Personal Selling \& Sales Management, 19(4), p. 21-40.

Wetzels,M., de Ruyter, K., Van Birgelen, M., 1998. Marketing service relationships: The role of commitment. Journal of Business \& Industrial Marketing, 13(4/5), p. 406-423.

Woo, K. -S., Ennew, C. T., 2004. Business-to-business relationship quality: An IMP interaction-based conceptualization and measurement. European Journal of Marketing, 38(9/10), p. 1252-1271. 


\section{ABOUT AUTHORS}

Ing. David Vykydal, Ph.D., VŠB -Technical University of Ostrava, Faculty of Metallurgy and Materials Engineering, Department of Quality Management, 17. listopadu, Ostrava-Poruba 708 33, Czech Republic, e-mail: david.vykydal@vsb.cz.

Ing. Mgr. Patra Halfarova, Ph.D., VŠB - Technical University of Ostrava, Faculty of Metallurgy and Materials Engineering, Department of Quality Management, 17. listopadu, Ostrava-Poruba 708 33, Czech Republic, e-mail: petra.halfarova@vsb.cz.

Prof. Ing. Jaroslav Nenadál, Ph.D., VŠB - Technical University of Ostrava, Faculty of Metallurgy and Materials Engineering, Department of Quality Management, 17. listopadu, Ostrava-Poruba 708 33, Czech Republic, e-mail: jaroslav.nenadal@vsb.cz. 